\title{
Sosialisasi Pengelolaan Sanitasi Bagi Kesehatan Keluarga
}

\author{
Nasaruddin Siregar ${ }^{1}$, Hasyim Purnama ${ }^{1}$, Sari Endah Nursyamsi ${ }^{1}$, Nita Komala Dewi ${ }^{2,}$ \\ ${ }^{1}$ Fakultas IImu Komunikasi; Universitas Bhayangkara Jakarta Raya; Jl. Raya Perjuangan, \\ Marga Mulya, Bekasi Utara, Jawa Barat 17143, telp/fax : 021- 88955882/021 - 88955881; e- \\ mail: anaktaborusiregar@gmail.com; hasyim.purnama@dsn.ubharajaya.ac.id; \\ sariendahn@gmail.com; \\ ${ }^{2}$ Fakultas Ekonomi dan Bisnis; Universitas Bhayangkara Jakarta Raya; Jl. Raya Perjuangan, \\ Marga Mulya, Bekasi Utara, Jawa Barat 17143, telp/fax : 021- 88955882/021 - 88955881; e- \\ mail: nita.komala@dsn.ubharajaya.ac.id \\ * Korespondensi: e-mail: nita.komala@dsn.ubharajaya.ac.id
}

\begin{abstract}
The problem of public self-awareness for environmental cleanliness is still minimal. Many people, especially in the area of Bekasi City, North Bekasi District, to be precise in Kelurahan Kaliabang Tengah, are still not aware of the cleanliness of their respective environment. The unbalanced population density with the land available for settlement results in irregular housing arrangements and the provision of basic facilities and infrastructure for human settlements as well as one of the consequences of poor environmental sanitation. So that the team of lecturers from the Faculty of Economics and Business and the Faculty of Economics and Business Ubhara Jaya are motivated to carry out community service in the area of Central Kaliabang with the theme of Health Communication Patterns to the People of Kaliabang Tengah Village through Kader Pkk in Management of Family Health Santitation. The method uses a direct I face-to-face socialization or counseling system with 24 participants consisting of women cadres PKK RW 015 Kelurahan Kaliabang Tengah, Bekasi Utara by providing light material and language that is easy to understand about clean water sources and latrine construction. The purpose of providing counseling or outreach is to contribute knowledge and insight to the community about the importance of maintaining family health sanitation hygiene. The results obtained from this activity were the enthusiastic attitude of the participants to continue or often carry out counseling or socialization activities related to environmental sanitation or family health sanitation.
\end{abstract}

Keywords: Clean Water Sources, Family Health Sanitation, Latrine Construction, Sanitation

\begin{abstract}
Abstrak
Problematika mengenai kesadaran diri masyarakat untuk kebersihan lingkungan masih minim banyak masyarakat yang khususnya didaerah Kota Bekasi Kecamatan Bekasi Utara tepatnya di Kelurahan Kaliabang Tengah yang masih belum sadar akan kebersihan lingkungannya masing - masing. Kepadatan penduduk yang tidak seimbang dengan lahan yang tersedia untuk pemukiman mengakibatkan ketidakaturan penataan tempat tinggal dan penyediaan sarana dan prasarana dasar pemukiman penduduk juga merupakan salah satu akibat buruknya sanitasi lingkungan. Sehingga tim dosen dari Fikom dan Fakultas Ekonomi dan Bisnis Ubhara Jaya termotivasi untuk melaksanakan pengabdian kepada masyarakat di wilayah kelurahan kaliabang tengah dengan tema Pola Komunikasi Kesehatan Kepada Warga Kelurahan Kaliabang Tengah Melalui Kader Pkk Dalam Pengelolaan Santitasi Kesehatan Keluarga. Metode dengan sistem sosialisasi atau penyuluhan langsung/tatap muka dengan jumlah peserta 24 orang yang terdiri dari Ibu - Ibu Kader PKK RW 015 Kelurahan Kaliabang Tengah, Bekasi Utara dengan memberikan materi yang ringan dan bahasa yang mudah dimengerti
\end{abstract}


tentang sumber air bersih dan pembuatan jamban. Tujuan dari pemberian penyuluhan atau sosialisasi untuk menyumbangkan ilmu dan wawasan kepada masyarakat mengenai pentingnya menjaga kebersihan sanitasi kesehatan keluarga. Hasil yang diperoleh dari kegiatan ini adanya sikap antusias dari peserta yang mengharapkan untuk sering dilakukan kegiatan penyuluhan atau sosialisasi yang berkaitan dengan sanitasi lingkungan atau sanitasi kesehatan keluarga.

Kata kunci: Sumber Air Bersih, Sanitasi Kesehatan Keluarga, Pembangunan Jamban, Sanitasi

\section{Pendahuluan}

Kebersihan lingkungan sangat penting bagi kelangsungan hidup masyarakat. Dimana hubungan manusia dan lingkungan dapat dikatakan sebagai satu kesatuan yang tidak dapat dipisahkan. Adanya kesadaran dari manusia untuk tetap menjaga kebersihan lingkungan merupakan sikap keserasian hidup antara manusia dengan lingkungannya. Seperti halnya banyaknya sampah yang berserakan dijalanan dan dibuang sembarangan oleh masyarakat ke sungai ataupun ke kali dilokasi sekitar tempat tinggal mengakibatkan lingkungan sekitar menjadi tidak sehat.

Berdasarkan hasil observasi, dimana problematika mengenai kesadaran diri masyarakat untuk kebersihan lingkungan masih minim banyak masyarakat yang khususnya didaerah Kota Bekasi Kecamatan Bekasi Utara tepatnya di Kelurahan Kaliabang Tengah yang masih belum sadar akan kebersihan lingkungannya masing - masing. Kepadatan penduduk yang tidak seimbang dengan lahan yang tersedia untuk pemukiman mengakibatkan ketidakaturan penataan tempat tinggal dan penyediaan sarana dan prasarana dasar pemukiman penduduk juga merupakan salah satu akibat buruknya sanitasi lingkungan.

Sanitasi lingkungan merupakan faktor penting yang harus diperhatikan, terutama sarana air bersih, ketersediaan jamban, pengolahan air limbah, pembuangan sampah, dan pencemaran tanah. Pembuangan tinja dapat secara langsung mengontami- nasi makanan, minuman, sayuran, air tanah, serangga dan bagian-bagian tubuh. Perlu pengaturan pembuangan sampah agar tidak membahayakan kesehatan manusia karena dapat menjadi gudang makanan bagi vektor penyakit. Sayuran yang dimakan mentah dapat menjadi media transmisi penyakit dari tanah yang tercemar tinja (Kasnodihardjo \& Elsi, 2013). Ketika masalah sanitasi muncul di kawasan permukiman padat yang tidak tertata dengan baik dan juga tidak ditangani dengan cara yang tidak saniter maka akan mencemari lingkungan sekitar.

Hasil wawancara singkat dengan Ibu Raden Rara Sri Setianingrum, S.Sos. selaku Lurah kaliabang Tengah (23/01/2020) yang mengatakan bahwa ada beberapa warganya yang masih kurang memahami arti dari kebersihan lingkungan, dikarenakan masih banyak warga yang membuang sampah sembarangan, baik di kali maupun di pinggiran jalan komplek perumahan.

Untuk itu, Beliau memiliki program kebersihan lingkungan yang disosialisasikan secara terus menerus kepada warga sekitar di Kelurahan Kaliabang Tengah. Namun pada 
kenyataannya, apa yang sudah diprogramkan tersebut tidak berjalan dengan baik, hal ini disebabkan tidak semua warga berperan serta memiliki kepedulian terhadap lingkungannya.

Seperti yang kita ketahui bahwa dengan kondisi lingkungan yang sehat dan bersih maka akan membuat masyarakat sekitar terhindar dari berbagai macam penyakit. Salah satu penyakit yang sering ada atas buruknya kebersihan yakni diare dan penyakit kulit.

Berdasarkan hal tersebut maka kami tim dosen dari Fikom dan Fakultas Ekonomi dan Bisnis Ubhara Jaya termotivasi untuk melaksanakan pengabdian kepada masyarkat di wilayah kelurahan kaliabang tengah. Kegiatan yang kami harapkan ini dapat membantu meningkatkan pengetahuan dan pemahaman dari warga mengenai sanitasi lingkungan dan membantu program dari lurah dalam meningkatkan kebersihan lingkungan melalui kadek ibu - ibu PKK.

\section{Metode Pelaksanaan}

Beberapa metode dalam pelaksanaan kegiatan pengabdian kepada masyarakat sebagai berikut :

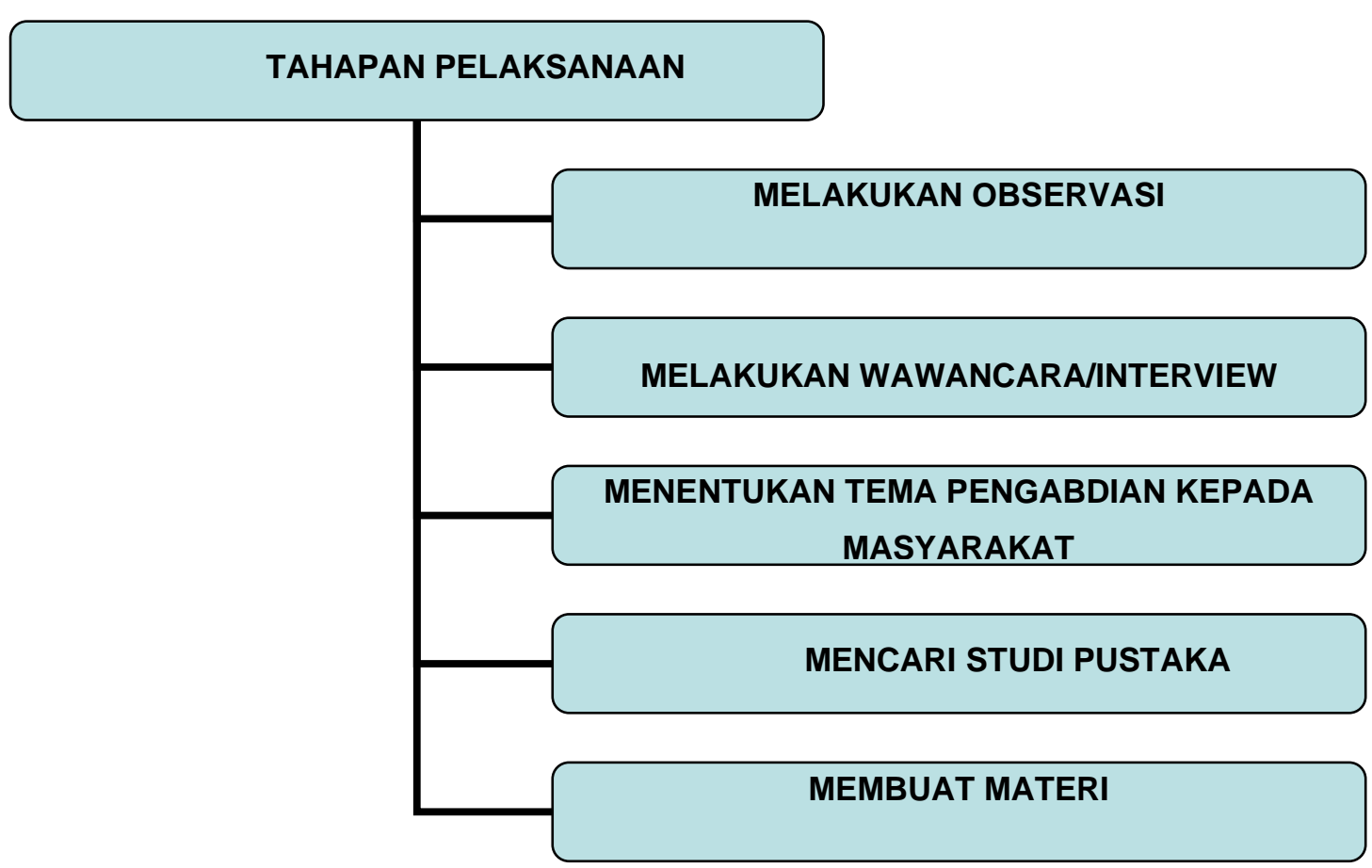

Sumber: Hasil Pelaksanaan (2020)

Gambar 1. Tahapan Pelaksanaan

Kegiatan observasi dilaksanakan sebagai langkah awal dalam melaksanakan kegiatan pengabdian kepada masyarakat dengan melihat adanya fenomena mengenai ketidak pemahaman akan komunikasi kesehatan yang ada di Kelurahan Kaliabang Tengah, Bekasi Utara khususnya dalam program sanitasi kesehatan keluarga. Kegiatan wawancara/interview yaang dilaksanakan secara langsung kepada Lurah dan beberapa warga sekitar serta ibu - ibu yang tergabung dalam organisasi PKK di Kelurahan Kaliabang Tengah, Bekasi Utara tentang program sanitasi kesehatan keluarga sehingga dapat mencegah terjangkit penyakit lingkungan. 
Berdasarkan pada hasil observasi dan wawancara/interview yang telah dilakukan pada awal langkah pengabdian, selanjutnya menentukan tema dari pengabdian kepada masyarakat yang akan dilaksanakan di Kelurahan Kaliabang Tengah, Bekasi Utara yakni sosialisai program Pola Komunikasi Kesehatan kepada Kader PKK Kelurahan Kaliabang Tengah Dalam Pengelolaan Santitasi Kesehatan Keluarga. Mencari dan menentukan studi pustaka sebagai bahan referensi yang akan digunakan sebagai ilmu penunjang yang berkaitan dalam kegiatan pengabdian.

Tahap terakhir berdasarkan dari pengumpulan beberapa data dan bahan referensi yang diperoleh dari studi pustaka dan hasil observasi serta hasil interview atau wawancara secara langsung dengan beberapa warga, maka kami membuat materi dalam bentuk power point dengan isi dan pesan serta bahasa yang mudah dipahami oleh peserta.

\section{Hasil dan Pembahasan}

\subsection{Pemberian Materi}

Berdasarkan pada hasil wawancara dan observasi mengenai permasalahan sanitasi kesehatan keluarga di lingkungan Kelurahan Kaliabang Tengah, Bekasi Utara, maka dituangkan dalam bentuk pengabdian kepada masyarakat dengan sistem sosialisasi melalui ibu - ibu Kader PKK (Pembinaan Kesejahteraan Keluarga) RW.015 Kel. Kaliabang Tengah, Bekasi Utara sebanyak 24 orang peserta dengan sistem sosialisasi secara langsung/tatap muka dengan tetap memperhatikan prosedur kesehatan Pandemi Covid 19. Kegiatan abdimas ini dilaksanakan di Aula Bank Sampah RW 015.

Tahap awal dari kegiatan ini adalah sambutan atau arahan dari lbu Lurah Kaliabang Tengah, Bekasi Utara yaitu Ibu Raden Rara Sri Setianingrum, SSos. Ibu Lurah memberikan arahan kepada tim pengabdi dan peserta untuk selalu menjaga kebersihan lingkungan tempat tinggal kita masing - masing, dengan tidak membuang sampah sembarangan, tetap menjaga sungai/kali untuk tetap bersih dan jernih dengan tidak mencemarinya dengan berbagai hal yang dapat merugikan warga baik yang tinggal di pinggiran sungai/kali maupun warga yang tinggalnya jauh dari sungai/kali. Kemudian tim dan peserta harus tetap memperhatikan protokol kesehatan dengan terus menggunakan masker selama kegiatan berlangsung.

Sesi selanjutnya yaitu sambutan/arahan dari Bapak Sumaryo selaku Ketua RW 015 yang memberikan ucapan terima kasih kepada tim pengabdi sudah dapat datang dan memberikan ilmu dan wawasan kepada peserta yang terdiri dari ibu - ibu kader PKK RW 015.

Dilanjut dengan sesi pemberian materi oleh tim pengabdi yang dibawakan secara ringan dengan bahasa yang mudah dimengerti oleh peserta. Adapun materi yang disampaikan oleh tim pengabdi sebagai berikut: Pengertian Sanitasi bagi kesehatan keluarga, dimana pemberian materi mengenai sanitasi bagi kesehatan keluarga merupakan informasi awal yang disampaikan oleh tim pengabdi berkaitan dengan hasil observasi yakni masih banyaknya masyarakat yang membuang sampah sembarangan dan tidak peduli dengan kebersihan lingkungan sekitar mereka tinggal. Pengertian sanitasi sangat luas. Dari sisi teknis, sanitasi 
melingkupi tiga unsur, yaitu: air limbah, persampahan, dan drainase lingkungan. Ketiga unsur sanitasi tersebut memiliki kompleksitas tersendiri. (Adhi, 2009).

Sanitasi disini adalah upaya yang dilakukan untuk merubah perilaku budaya hidup bersih dan sehat dengan tidak buang air besar sembarangan, mencuci tangan pakai sabun, mengelola air minum dan makanan yang aman, mengelola sampah rumah tangga dengan aman dan mengelola limbah cair rumah tangga dengan aman (Nursalim et al., 2020).

Fasilitas Sanitasi di sini dimaksudkan sarana fisik bangunan dan perlengkapannya yang digunakan untuk memelihara kualitas lingkungan atau mengendalikan faktor-faktor lingkungan fisik yang dapat merugikan kesehatan manusia. Sehingga sanitasi bagi kesehatan keluarga merupakan cara atau usaha menjaga lingkungan kesehatan didalam ruang lingkup keluarga dengan memperhatikan kebersihan dari sanitasi yang berkaitan dengan lingkungan keluarga. Salah satu dari sanitasi bagi kesehatan keluarga dapat diambil contoh sumber air bersih dan pembuatan jamban yang menjadi perhatian dalam ruang lingkup kebersihan keluarga.

Materi berikutnya mengenai kebersihan sumber air bersih. Sumber air terdiri dari beberapa macam. Meskipun tidak semua dapat dimanfaatkan sebagai akses air bersih untuk keperluan air minum, namun terdapat jenis sumber air yang dekat dengan manusia dan menjadi sumber air untuk pemanfaatan sekunder. Contoh dari pemanfaatan sekunder adalah air sebagai irigasi perkebunan atau kebutuhan air bagi peternakan, serta tempat rekreasi keluarga (Setyaningrum, 2015).

Berikutnya mengenai materi Pengetahuan Pembuatan Jamban. Di dalam Peraturan Menteri Pekerjaan Umum nomor 16/2008 tentang Kebijakan dan Strategi Nasional Pengembangan Sistem Pengelolaan Air Limbah Permukiman tidak disebutkan adanya istilah jamban. Namun di dalam Keputusan Menteri Permukiman dan Prasarana Wilayah nomor 534/2001 tentang Pedoman Standar Pelayanan Minimal disebutkan adanya sarana sanitasi individual dan komunal berupa jamban beserta MCK- nya. Lebih jauh lagi di dalam Buku Panduan Penyehatan Lingkungan Permukiman untuk RPIJM 2007 disebutkan adanya pengumpulan data primer tentang jamban keluarga. Di dalam Petunjuk Teknis Tata Cara Pembuatan Bangunan Jamban Keluarga dan Sekolah 1998 dari Departemen Pekerjaan Umum, disebutkan bahwa jamban mencakup bangunan atas yang antara lain terdiri: plat jongkok, leher angsa, lantai, dinding, dll, tetapi tidak termasuk bangunan bawahnya (Otaya, 2012).

Syarat jamban yang sehat sesuai kaidah-kaidah kesehatan, sebagaimana yang dikemukakan Mutmainna (2009:1) adalah 1) tidak mencemari sumber air minum; 2) tidak berbau tinja dan tidak bebas dijamah oleh serangga maupun tikus; 3) air seni, air bersih dan air penggelontor tidak mencemari tanah sekitar olehnya itu lantai sedikitnya berukuran $1 \times 1$ meter dan dibuat cukup landai, miring kearah lobang jongkok; 4) mudah dibersihkan dan aman penggunaannnya; 5) dilengkapi dengan dinding dan penutup; 6) cukup penerangan dan sirkulasi udara; 7) luas ruangan yang cukup; h. Tersedia air dan alat pembersih (Otaya, 2012).

Dalam pembahasan materi tersebut di atas tim memfokuskan mengenai sanitasi bagi kesehatan kepada sumber air bersih dan pembuatan jamban. Dari penjelasan melalui 
sosialisasi dengan suasana yang santai ternyata masih ada beberapa peserta yang tidak mengetahui bagaimana caranya untuk bisa menjaga kebersihan sanitasi kesehatan keluarga. Sehingga pemberian materi ini secara tidak langsung membantu peserta untuk mendapatkan tambahan ilmu dan wawasan mengenai sumber air bersih dan pembuatan jamban, karena selama ini banyak warga yang tinggal di RW 015 yang belum mengetahui dan lebih bersikap tidak peduli dengan kebersihan sanitasi bagi kesehatan keluarga.

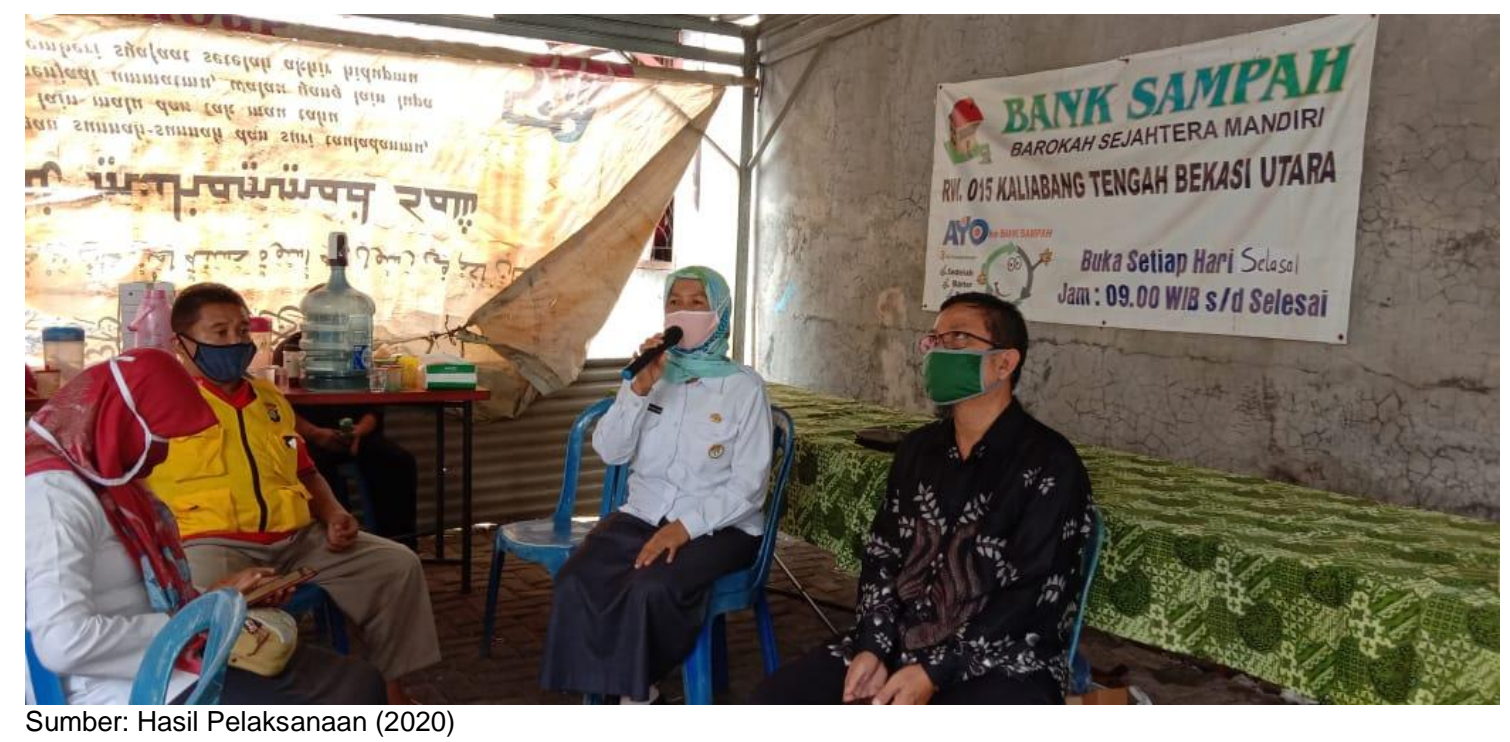

Gambar 2. Sambutan dari Ibu Lurah Kelurahan Kaliabang Tengah, Bekasi Utara

Gambar 3 menunjukkan kegiatan pelaksanaan pengabdian kepada masyarakat dalam penyampaian materi yag dipaparkan langsung oleh tim pegabdi kepada masyarakat.

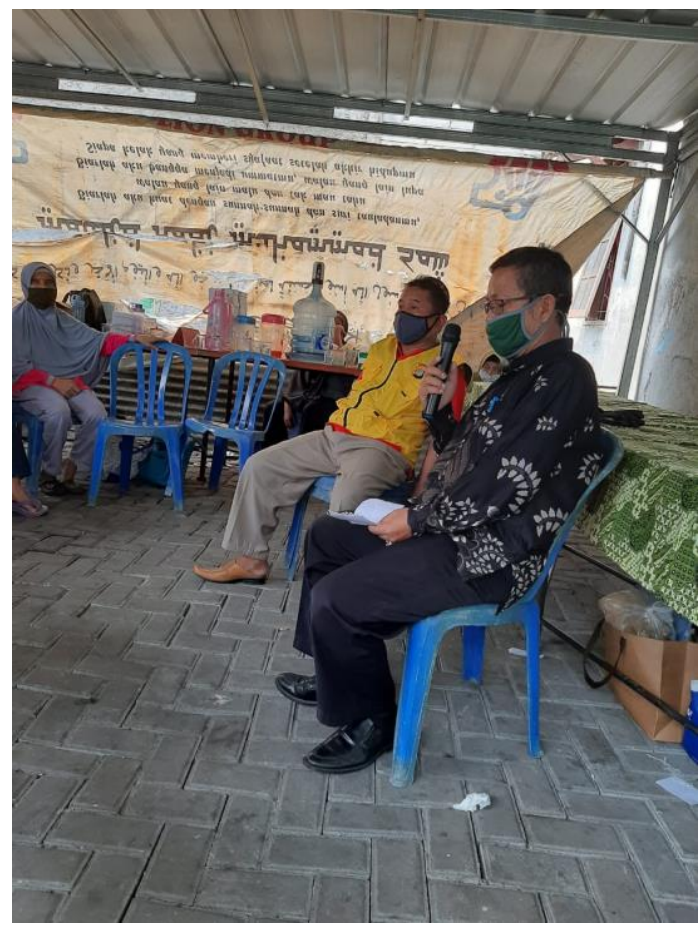

Sumber: Hasil Pelaksanaan (2020)

Gambar 3. Pemberian Materi Oleh Tim Pengabdi Kepada Peserta 
Gambar 4 menunjukkan antusias para peserta kegiatan pengabdian kepada masyarakat yang diikuti oleh lbu kader PKK Kelurahan Kaliabang Tengah, Bekasi Utara.

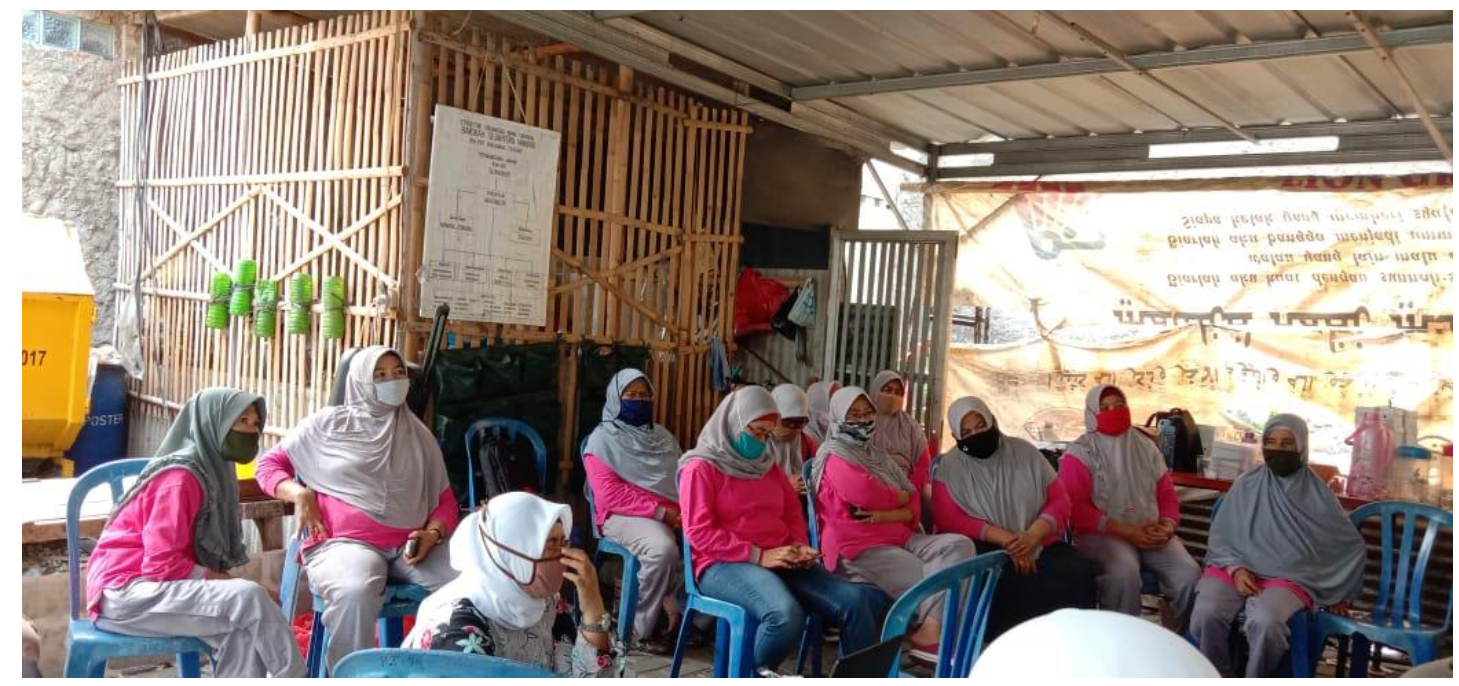

Sumber: Hasil Pelaksanaan (2020)

Gambar 4. Peserta Abdimas Kader PKK Kelurahan Kaliabang Tengah, Bekasi Utara

\subsection{Hasil}

Tahap awal dalam kegiatan abdimas ini tim pengabdi melakukan wawancara awal dan observasi ke lokasi yakni keluarahan kaliabang tengah, Bekasi utara. Wawancara awal dilakukan untuk mengetahui mengenai permasalahan yang dimiliki oleh warga sekitar kelurahan kaliabang tengah khsusunya warga yang bermukim di RW 015 dengan target awal dari abdimas ini ibu - ibu yang tergabung dengan Kader PKK Kelurahan kaliabang tengah, Bekasi utara.

Wawancara dilakukan pertamakali dengan ibu lurah kelurahan kaliabang tengah, Bekasi Utara yakni ibu Raden Rara Sri Setianingrum, SSos selaku Lurah Kaliabang Tengah (23/01/2020) yang akrab dipanggil Ibu Sri. Dalam hasil wawancara tersebut ibu lurah menyampaikan bahwa masih banyak warganya yang tidak patuh dan peduli terhadap lingkungan tempat tinggal mereka. Masih banyaknya warga yang membuang sampah sembarangan ke sungai/kali. Sedangkan air kali/sungai selama ini masih digunakan oleh warga untuk memenuhi kebutuhan sehari - hari seperti MCK (Mandi, Cuci, Kakus).

Hasil observasi sendiri untuk mengetahui kebenaran apa yang didapat dari hasil wawancara dengan ibu Lurah Kaliabang Tengah, Bekasi Utara mengenai warganya yang masih melakukan ketidak pedulian dan patuh untuk menjaga kebersihan lingkungan tempat tinggal mereka sendiri.

Kegiatan abdimas dilaksanakan yakni hari Selasa, 15 September 2020 di Aula Bank Sampah RW 015 Kel. Kaliabang Tengah, Bekasi Utara dengan peserta sebanyak 24 orang yang terdiri dari ibu - ibu Kader PKK. Penyampaian sosialisasi mengenai tema abdimas yakni Pola Komunikasi Kesehatan kepada Warga Kelurahan Kaliabang Tengah Melalui Kader PKK. 
Dalam Pengelolaan Santitasi Kesehatan Keluarga disampaikan oleh tim abdimas dengan menggunakan bahasa yang ringan sehingga memudahkan peserta untuk mengerti arti dan maksud dari materi yang disampaikan.

Pemberian materi lebih dikhususkan kepada sanitasi kebersihan sumber air bersih dan pembuatan jamban. Mengingat daerah Bekasi itu sendiri banyak dilalui oleh sungai/kali serta informasi cara pembuatan jamban perumahan. Mengenai sumber air yang harus dipahami oleh peserta yakni bahwa air berwarna bening saja bukan berarti air itu sudah layak dikonsumsi untuk kegaitan sehari - hari. Ada beberapa ciri - ciri dari air yang dinyatakan sebagai sumber air bersih yakni jernih, tidak berbau, tidak mempunyai rasa, tidak berwarna dalam hal ini semua air bersih tidak terkontaminan dengan zat kimia dan sesuai standar WHO. Dalam pembuatan jamban tersendiri, tim pengabdi menjelaskan dalam slide materi mengenai cara penentuan lokasi, jarak dan efek yang ditimbulkan dari pembuatan jamban yang salah.

Peserta sosialisasi terlihat antusias mendengarkan penjelasan dari tim pengabdi dan kadang - kadang menghentikan ceramah untuk bertanya, dikarenakan ada beberapa peserta yang kurang memahami bagaimana caranya mendapatkan sumber air bersih dan pembuatan jamban yang benar sesuai ketentuan Depkes.

Dari sesi tanya jawab banyak pertanyaan yang disampaikan oleh peserta. Pertanyaan menarik dari kedua materi yang disampaikan tersebut yakni bagaimana cara mendapatkan sumber air bersih untuk pemukiman yang pada pendududuk dan cara menentukan jarak yang benar saat ingin membuat jamban. Informasi yang disampaikan oleh tim pengabdian bahwa untuk mendapatkan sumber air bersih yang benar di tengah-tengah pemukiman yang padat penduduk dengan cara menjaga sumber air dengan memperhatikan jarak sumber air dengan jamban dan tempat pembuangan sampah paling sedikit $10-15$ meter. Selalu menjaga kebersihan dari sumur gali dengan memperhatikan lantai sumur yang tidak boleh retak, bibir sumur harus di plester dan diberikan penutup untuk sumur gali agar tidak ada kotoran, lantai dan dinding sumur tidak berlumut. Alat yang digunakan untuk mengambil air juga harus bersih. Meski terlihat bersih dan jernih airnya belum tentu bebas dari kuman - kuman penyakit.

Efek tidak memperhatikan kebersihan tersebut maka akan menimbulkan berbagai macam penyakit yang disebabkan oleh mikro organisme yang berpindah dari air ke manusia. Penyakit yang disebabkan dari air yang tidak bersih yakni waterborne diseases, Waterwashed diseases, Water based diseases, Water related insect vector disease (Priyanto, 2011).

Adapun kendala yang dihadapi oleh peserta dalam memperoleh air bersih, bahwa wilayah RW 015 ini merupakan salah satu pemukiman yang padat penduduk sehingga untuk mendapatkan sumber air yang bersih itu sulit dikarenakan jarak antara rumah satu dengan yang lainnya berdekatan sehingga sulit menentukan jarak aman untuk mendapatkan sumber air bersih. Terlontar pula warga ingin membangun sumber air bersih yang tata letaknya jaraknya sesuai dengan ketentuan dan nanti air tersebut akan dialirkan ke rumah - rumah yang akan dipakai untuk kebutuhan sehari-hari. 
Selain sumber air bersih, pertanyaan selanjutnya menentukan jarak yang benar saat ingin membuat jamban. Menjawab pertanyaan tersebut tim pengabdi menjelaskan bahwa sebelum menentukan jarak yang benar peserta harus mengetahui tentang syarat - syarat dari jamban sehat yakni : tidak mencemari sumber air minum, tidak berbau, kotoran tidak dapat dijamah oleh serangga dan tikus, tidak mencemari tanah di sekitarnya, mudah dibersihkan dan aman digunakan, dilengkapi dinding dan atap pelindung, penerangan dan ventilasi cukup, lantai kedap air dan luas ruangan memadai, tersedia air, sabun, dan alat pembersih. Berkaitan dengan hal tersebut maka untuk menentukan jarak yang benar dalam pembuatan jamban yakni kurang lebih 10-15 meter, memperhatikan kondisi dataran (datar/miring), tinggi rendahnya permukaan air, arah aliran air tanah, sifat, dan macam dan struktur tanah untuk mencegah tercemarnya sumber air dan menghindari timbulnya berbagai macam penyakit yang dibawa oleh mikro organisme melalui air kepada manusia.

Dengan adanmya sikap antusias dari peserta maka peserta mengharapkan agar ada lagi kegiatan seperti ini selain menambah wawasan dan ilmu juga bisa membantu warga sekitar untuk sadar akan kebersihan lingkungannya, agar tidak tercemarkannya sumber air bersih sehingga terhindar dari penyakit - penyakit menular.

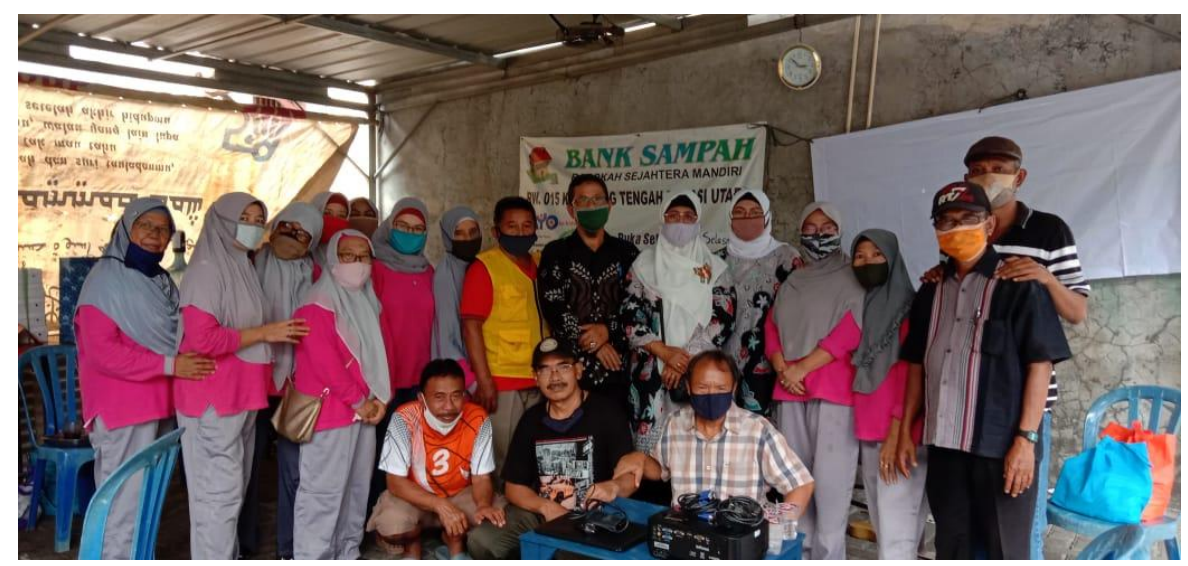

Sumber: Hasil Pelaksanaan (2020)

Gambar 5. Foto bersama Ketua RW 015 dan Tim Pengabdi

\section{Kesimpulan}

Adanya sikap keserasian dalam hidup antara manusia dengan lingkunganya yang didasari oleh kesadaran diri untuk tetap menjaga lingkungannya agar tetap bersih dan nyaman. Kesadaran diri yang dimiliki oleh warga Kaliabang Tengah, Bekasi Utara yang dilihat masih kurang, dikarenakan masih banyaknya warga yang membuang sampah sembarangan. Sehingga masalah sanitasi muncul di wilayah tersebut karena tidak tertata dengan baik dan juga tidak ditangani dengan cara yang tidak saniter maka akan mencemari lingkungan sekitar.

Berdasarkan hal tersebut kegiatan pengabdian kepada masyarakat dengan tema Pola Komunikasi Kesehatan melalui Kader PKK Kelurahan Kaliabang Tengah Dalam Pengelolaan Santitasi Kesehatan Keluarga dengan cara sosialisasi yang dilaksanakan pada hari selasa, 15 September 2020 dengan dihadiri oleh 24 orang peserta dari Kader PKK RW 015 Kel. Kaliabang 
Tengah, Bekasi Utara. Pemahaman dari peserta yang minim mengenai sanitasi kesehatan untuk sumber air bersih dan pembuatan jamban, sehingga adanya kegiatan ini menambah ilmu dan wawasan dari peserta mengenai sanitasi kesehatan keluarga.

\section{Daftar Pustaka}

Adhi, E. T. (2009). Pelayanan Sanitasi Buruk Akar Dari Kemiskinan. Jurnal Analisis Sosial, 14, 76-88.

Kasnodihardjo, K., \& Elsi, E. (2013). Deskripsi Sanitasi Lingkungan, Perilaku Ibu, dan Kesehatan Anak. Kesmas: National Public Health Journal, 7(9), 415. https://doi.org/10.21109/kesmas.v7i9.14

Kemenkes. (2008). Strategi Nasional Sanitasi Total Berbasis Masyarakat. Kepmenkes RI No 852, 1-11. Retrieved from http://www.un.org/millenniumgoals/

Komariah, K., Perbawasari, S., Nugraha, A. R., \& Budiana, H. R. (2013). Pola Komunikasi Kesehatan Dalam Pelayanan Dan Pemberian Informasi Mengenai Penyakit Tbc Pada Puskesmas Di Kabupaten Bogor. Jurnal Kajian Komunikasi, 1(2), 173-185. https://doi.org/10.24198/jkk.vol1n2.7

Nursalim, N., Saputri, M. M., Nurlinda, N., Muhammad, S., Jumawati, J., J, I., ... Hidayatullah, M. (2020). Pembinaan Masyarakat Dalam Perbaikan Sanitasi Lingkungan. INTEGRITAS: $\quad$ Jurnal Pengabdian, 95. https://doi.org/10.36841/integritas.v4i1.521

Otaya, L. G. (2012). Pengetahuan, Sikap Dan Tindakan Masyarakat Terhadap Penggunaan Jamban Keluarga. Jurnal Health and Sport, 5(2), 13-26.

Priyanto, D. (2011). Peran Air Dalam Penyebaran Penyakit. Balaba, 7, 27-28.

Setyaningrum, S. (2015). Kontaminasi Patogen pada Sumber Air dan Upaya Penyisihan Patogen dalam Proses Produksi Air Bersih. Institut Teknologi Bandung, (December), $1-9$.

Retrieved from https://www.researchgate.net/profile/Sinta Setyaningrum2/publication/287571325

Tumanggor, R. (2010). Masalah - Masalah Sosial Budaya Dalam Pembangunan Kesehatan di Indonesia. Jurnal Masyarakat Dan Budaya, 12(2), 231-254. 